University of Michigan Law School

University of Michigan Law School Scholarship Repository

\title{
Importing Prescription Drugs from Canada - Legal and Practical Problems with the Trump Administration's Proposal
}

\author{
Rachel E. Sachs \\ Washington University School of Law \\ Nicholas Bagley \\ University of Michigan Law School, nbagley@umich.edu
}

Available at: https://repository.law.umich.edu/articles/2217

Follow this and additional works at: https://repository.law.umich.edu/articles

Part of the Food and Drug Law Commons, Health Law and Policy Commons, and the International Trade Law Commons

\section{Recommended Citation}

Sachs, Rachel E. "Importing Prescription Drugs from Canada - Legal and Practical Problems with the Trump Administration's Proposal." Nicholas Bagley, co-author. New Eng. J. Med. 382, no. 19 (2020): 1777-9.

This Article is brought to you for free and open access by the Faculty Scholarship at University of Michigan Law School Scholarship Repository. It has been accepted for inclusion in Articles by an authorized administrator of University of Michigan Law School Scholarship Repository. For more information, please contact mlaw.repository@umich.edu. 

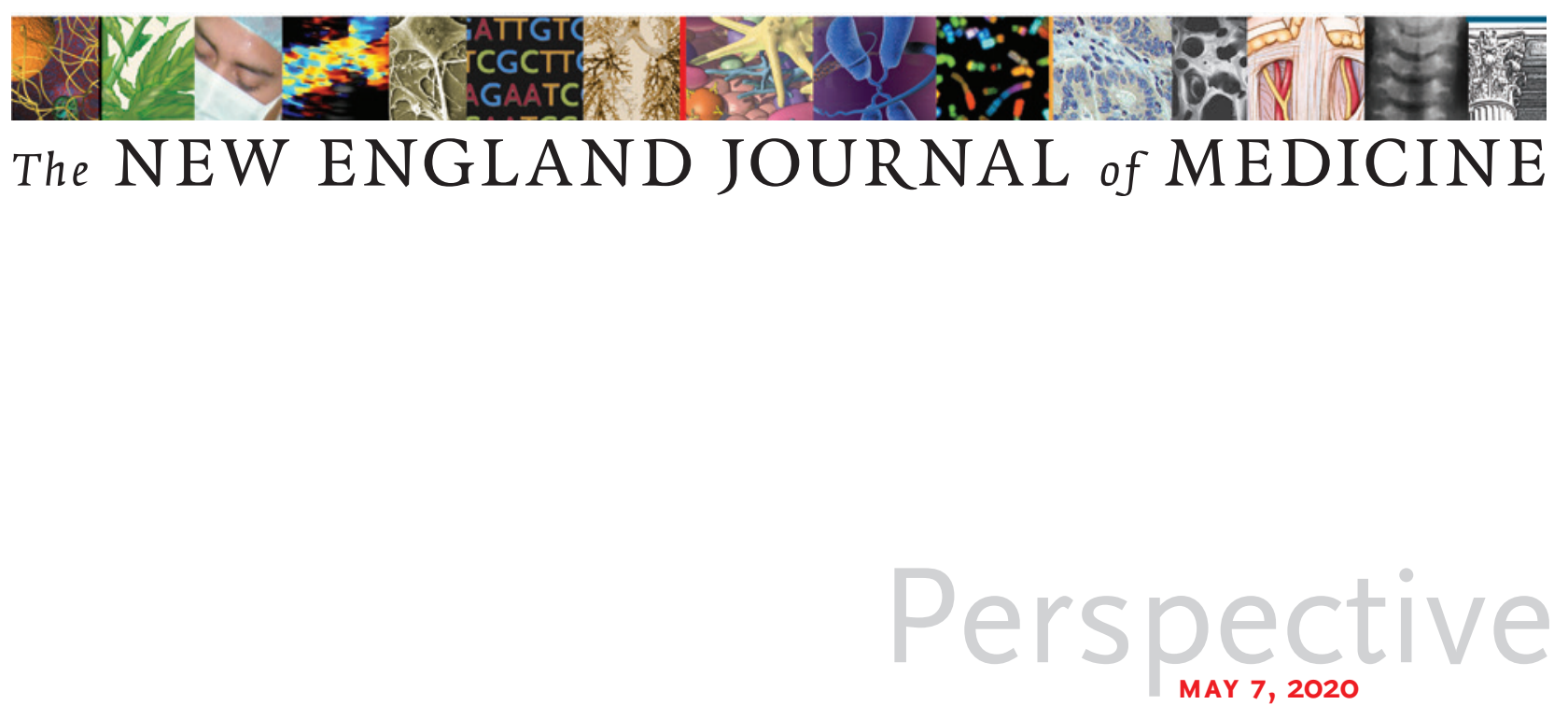

\section{Importing Prescription Drugs from Canada - Legal and Practical Problems with the Trump Administration's Proposal}

Rachel E. Sachs, J.D., M.P.H., and Nicholas Bagley, J.D.

\section{A s Americans report ever-growing difficulty affording their prescription drugs, President Donald Trump has come under increasing pressure to act. To date, the Trump administration}

has attempted to advance a number of policy initiatives by means of executive action, but it has not yet adopted a program that would meaningfully assist patients. Most recently, the administration proposed a rule that, if finalized, would allow states to develop programs to import lower-priced prescription drugs from Canada, with the intent of reducing spending on drugs by U.S. patients and states and increasing access for patients. ${ }^{1}$

A careful review of the importation proposal, however, suggests that it is both unlikely to be successful in lowering drug prices and possibly unlawful. To the extent that it would achieve anything at all, it would do so not by improving the system for pricing drugs in the United States, but by outsourcing the responsibility for addressing high U.S. drug prices to Canada. Far from a bold initiative to help people afford their prescription drugs, the proposal seems designed to allow the Trump administration to claim that it is taking action, even as it opposes congressional legislation that would sharply curb some drug prices.

The legal authority for allowing large-scale importation of prescription drugs from Canada is not new. In the 2003 law creating Medicare Part D, Congress authorized such importation - but "only if the Secretary [of Health and Human Services (HHS)] certifies to the Congress" that it will both "pose no additional risk to the public's health and safety" and "result in a significant reduction in the cost of covered products to the American consumer." Until now, HHS officials have been unwilling to make the required certification, partly because the U.S. Food and Drug Administration (FDA) could not ensure the safety of imported drugs and partly because total savings attributable to importation would be small.

But policymakers in states as politically diverse as Vermont, Florida, Colorado, Maine, and New Mexico have been pressuring the Trump administration to permit importation. Each of these states has passed a law seeking the flexibility to purchase lowerpriced Canadian medicines for its residents (see map). In response, HHS has proposed delegating to the states the responsibility of creating their own plans for drug importation. These state-based importation programs would iden- 


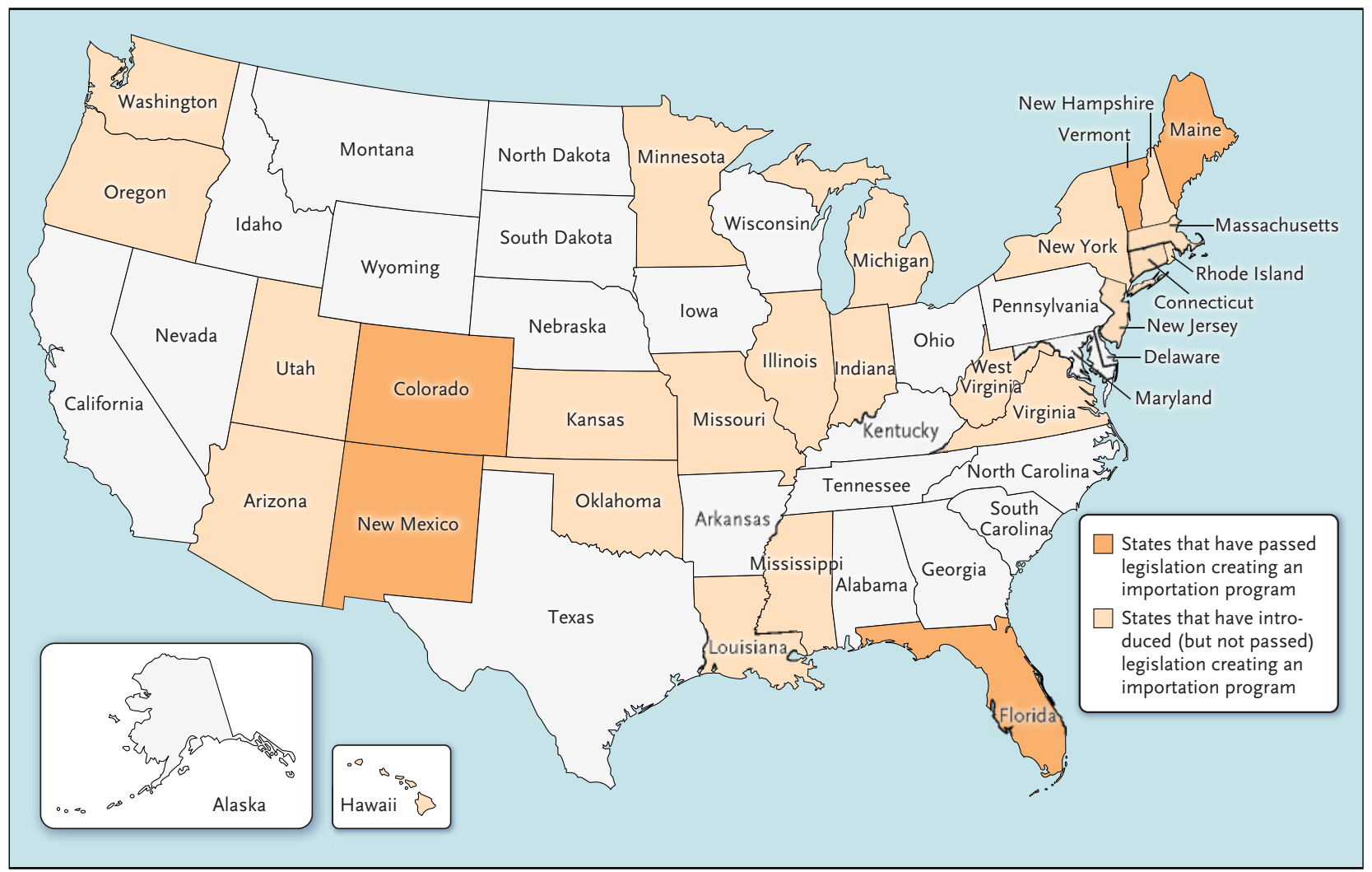

State Legislation on Drug Importation, 2018-2020.

Information is as of March 11, 2020, and is from the National Academy for State Health Policy. The map does not show states that have introduced but not passed legislation to investigate a possible importation program (including Wyoming).

tify a Canadian wholesaler that buys drugs directly from manufacturers and is willing to sell those drugs to partners in the United States. The program would also have to enlist an American wholesaler or pharmacy to purchase the drugs from the Canadian wholesaler. With that arrangement in place, a state would then need to show to HHS's satisfaction that its plan is likely to save money and protect patient safety. If it did so, HHS would allow the state to conduct a 2-year importation program, subject to future reauthorization.

Having laid out the rules for state programs, the Trump administration claims that it is now in a position to make the certification to Congress that the 2003 law requires. But that claim is a strange one to make, given that HHS has not concluded either that importing drugs would pose no public health risks or that it would save money. Rather, HHS means to issue a kind of conditional certification to Congress: if a state demonstrates that it can meet the required conditions, then the agency will approve the state's importation plan.

This approach to importing drugs from Canada raises at least three issues regarding legality and feasibility. First, HHS may not have the legal authority to certify to Congress that entirely hypothetical state plans will save money and not pose health risks until the agency has had an opportunity to evaluate them. In- deed, HHS acknowledges in the proposed rule that it is "unable to estimate the cost savings" at this point, since potential savings would depend entirely on the details of states' importation proposals. Yet certification ought to come after evaluation, not before it. As one appeals court has held in a similar context, "the very structure of the statute" may preclude the agency from making a congressional certification in advance of the facts. ${ }^{3}$

Second, HHS has offered very limited guidance to the states on how they might show that importation will reduce costs. In a terse two paragraphs, the proposal envisions that states could compare the "anticipated acquisition costs" or the "current retail cash 
price[s]" of drugs in Canada and the United States. Because prescription drugs are far more expensive in the United States than they are in Canada - sometimes many times more expensive straightforward price comparisons would show that importation would save money.

Such a blunt approach, however, appears certain to yield wildly inflated savings estimates. Canadian regulators and the pharmaceutical industry, both of which oppose the proposal, would not stand by and watch as drugs are imported into the United States. Regulators might change their rules to discourage exportation, and the industry might adjust contractual terms with Canadian entities that would prevent or at least deter intermediaries from partnering with importation programs. In addition, any savings could accrue to the wholesalers conducting the cross-border sale or to the providers prescribing the imported drugs, rather than to U.S. patients. Importation might still save money, at least for some drugs ${ }^{4}$ but a raw comparison of prices in the United States and Canada provides very thin support for that conclusion. Pointing specifically to these types of con- cerns, the FDA has questioned "whether this proposed rule could yield non-zero benefits." ${ }^{5}$ The courts could well put a stop to such an arbitrary approach to estimating savings.

Third, the proposal asks states to assemble certain types of information to show that importation would pose no risks to public safety, including information on supply-chain security guarantees and testing requirements. But it is perplexing that the federal government would ask states to gather and submit information that the FDA has already collected. It may not even be possible for states to gather the requested information - indeed, the proposal explicitly acknowledges that states "may not know whether" a drug they propose to import meets the FDA's requirements.

The administration's proposal is thus both puzzling from a policy standpoint and legally dubious. At least some of these problems could have been avoided if the Trump administration had moved to adopt its own importation program, as the 2003 law seemingly contemplates.

So why punt to the states? As with several of the administration's other executive actions on drug pricing, the proposal appears to be political theater, de- signed to mollify the public and restive states without overly antagonizing the pharmaceutical industry. But the Trump administration should get no credit for a step of questionable legality that will not help the vast majority of Americans afford their prescription drugs - especially because it has rejected reform proposals from states that drew the concentrated ire of drug manufacturers.

If states and the American public want lower drug prices, this proposal won't help. They will need to push the federal government to do more than pay lip service to the urgent need to constrain spending on prescription drugs.

Disclosure forms provided by the authors are available at NEJM.org.

From the Washington University School of Law, St. Louis (R.S.); and the University of Michigan Law School, Ann Arbor (N.B.).

1. Food and Drug Administration. Importation of prescription drugs: proposed rule. Fed Regist 2019;84(246):70796-839.

2. Importation of prescription drugs, 21 U.S.C. $\$ 384$.

3. National Treasury Employees Union v. Reagan, 663 F.2d 239 (D.C. Cir. 1981).

4. Fralick M, Kesselheim AS. The U.S. insulin crisis - rationing a lifesaving medication discovered in the 1920s. N Engl J Med 2019;381:1793-5.

5. Food and Drug Administration. Importation of prescription drugs: preliminary regulatory impact analysis. December 23, 2019 (https://www.fda.gov/media/133553/download). DOI: 10.1056/NEJMp2000464

Copyright @ 2020 Massachusetts Medical Society.

\section{Implementing the Cures Act - Bringing Consumer Computing to Health Care}

Donald W. Rucker, M.D.

Smartphones and electronic $\checkmark$ transparency have transformed our lives and the U.S. economy. Yet health care remains a stark exception. When health informa- tion is available, it tends to be accessible only in ways that bind patients to their current health care providers and insurance plans. Medical and cost informa- tion is far more helpful if patients can use it on their own terms, with tools of their own choosing. In the decades since the passage of the Stabilization Act of 1942 